The restructuring of the Hong Kong economy in the 1980s is an often told stoming iseaspre-published version Greenwood 1990; Lui and Chiu 1993; Mok 1993). Between 1981 and 1991 the absolute level of employment in the manufacturing sector declined from 990,000 to 768,000 (employment share fell from 41 percent to 28 percent). The decline of manufacturing industries was associated with the growing importance of the services sector. Employment share in financing, insurance, real estates and business services, for example, more than doubled in ten years (Census and Statistics Department 1992). During this period economic reform in China reinvigorated Hong Kong's links to the Chinese economy. Total trade with China increased more than twelve fold. Outward processing trade with China was almost non-existent in the early 1980s; in 1991 Hong Kong people sent $\$ 114$ billion worth of raw materials and semi-manufactures into China for processing, and received $\$ 197$ billion worth of processed goods. The estimated value added from outward processing was then $\$ 83$ billion. To put this figure in perspective, the total value added from the domestic manufacturing sector was $\$ 93$ billion in 1991 (Annual Digest of Statistics, various issues). The shift of Hong Kong's manufacturing base is unmistakable.

The changing sectoral composition of the Hong Kong economy raises concerns that range from labor shortage to unemployment. Wong et al. (1991) argue that economic restructuring fuels wage growth which in turn increases inflation. Labor advocates contend that de-industrialization causes relocation problems especially among older and less skilled workers. Policy recommendations to deal with the problems of structural transformation are rife, though there is little consensus as to what these problems really are. This paper brings data that bear on the question, How did Hong Kong workers fare under structural transformation? While theory about the functioning of labor markets offers some guidance, the question must ultimately be settled on empirical grounds. After a brief description of the pattern of sectoral shifts in Hong Kong, the paper addresses the following issues: (1) What were the effects of sectoral shifts on sectoral wage patterns? (2) Did relative wage for older and less educated workers fall? (3) Were there significant labor market frictions in the adjustments to economic transformation? The main findings are summarized in the concluding section of the paper. 


\section{Changes in Employment Patterns}

While the public were not concerned about structural change in Hong Kong until very recently, Table 1 shows that the relative decline of manufacturing employment has started since the early 1970s. Similarly employment in financial and business services has grown steadily for the past thirty years before Hong Kong emerged as one of the world's leading financial centers. If sectoral shifts are not a recent phenomenon, is there anything special about the changes during the 1980s?

Table 2 offers a partial answer. Columns (1) and (2) of the table shows the index of sectoral shift for various periods. The index is calculated by the expression $\sum_{i} \mid s_{i t}-$ $s_{i t^{\prime}} \mid / 2$ where $s_{i t}$ is the employment share of sector $i$ in year $t$. This index can be interpreted as the minimum proportion of workers who have to change sectors as a result of sectoral shifts. An alternative measure for the extent of sectoral shift, shown in columns (3) and (4) of Table 2, is the standard deviation of the growth rates of employment across different sectors. Both measures indicate that the pace of sectoral shift was faster in the 1980s than in earlier periods. The trend towards faster structural change was particularly evident for the second half of the eighties.

That the pace of structural shift was picking up in the late eighties can also be verified from international comparison. Table 3 shows the index of sectoral shift for Hong Kong, Singapore, South Korea, Japan and the United States. As in Young (1992), the rate of structural transformation in Hong Kong was below that in Singapore and in South Korea during the early eighties. However, this result does not hold for the more recent period. The rate of structural change in Hong Kong surpassed other countries in the period 1987-92. The accelerated pace of structural change suggests that the public's growing interest in this issue is not entirely unjustified.

To gain a more detailed picture beyond the broad trends of de-industrialization and the rise of services, a closer look at employment patterns at the two-digit level is necessary. To this end, I have constructed a data set from the 1976, 1981, 1986 and 1991 census one percent files. I recoded the industry codes for the economically active 
population to conform to the 1991 classification system. ${ }^{1}$ This produces 25 two-digit industries that are comparable across different years. ${ }^{2}$ For each industry I computed the total count of the number of persons engaged in that industry, their average monthly earnings, and a number of other sample characteristics. The result is a cross section of 25 industries repeated over 4 time periods at five year intervals.

Consistent with the findings from more aggregated data, this data set of twenty five industries indicates accelerated structural change. The rates of economic transformation were $9.01,8.51$, and 10.20 for the periods 1976-81, 1981-86, and 1986-91, respectively. Moreover the change in employment shares are serially correlated: the Pearson correlation coefficient between the change in employment shares in 1976-81 and that in 1986-91 is .30. This suggests the sectoral shifts represent permanent change rather than temporary aberrations or mere measurement errors.

The finer classification of industries afforded by my data set also confirms the broad trends shown in more aggregate data. Of the nine manufacturing industries in the census data, none gained employment share. Thus the decline of manufacturing industries is not confined to the hardest hit sectors (notably textiles, apparel, and plastic and rubber products). Similarly the growing importance of services is not limited to the financial sector. Among the fourteen services industries in the census data, only wholesale and retail trade experienced a drop in employment share.

Another trend evident in the structural transformation of the Hong Kong economy is the shift in occupational composition of the labor force. Unfortunately the occupational classification used in the 1991 census was based on a different set of criteria than those

1 There are no industry codes for the unemployed in the 1991 census. So the 1991 sample only consists of the employed population. Because of the small number of people is some industries, I have excluded those industries from the sample. Details of the recoding are available from me.

2 The industries are: electricity, gas and water (4); food, beverages and tobacco (31); textiles (32); wearing apparel (33); footwear and leather products (34); wood and wood products (35); paper products, printing and publishing (36); chemicals, rubber and plastic products (38); basic metal industries and metal products (39); machinery and electronic products (40); construction (51); wholesale trade (61); retail trade (62); import and export trade (63); restaurants and hotels (64); transport and related services (71); storage and warehouses (72); communications (73); banking and finance (81); insurance (82); real estate (83); business services (84); community and social services (91); recreational and cultural services (92); and personal and household services (93). 
used in earlier censuses. To maintain consistency across census years, I can only recode the occupations into very broad groups: managers and administrators (1); professionals and associate professionals $(2,3)$; clerks (4); service workers and shop workers (5); craft and related workers, plant and machine operators and assemblers (7, 8); elementary occupations (9); and others (0). ${ }^{3}$ As expected, there was a general upgrading in the distribution of occupations. The proportion of workers who were managers and administrators rose from 5.0 percent in 1976 to 9.1 percent in 1991; and the proportion of professionals and associate professionals increased from 7.0 percent to 14.7 percent.

Table 4 shows how the changing distribution of occupations varies across industries. Perhaps the most interesting feature of the table is that the increase in percentage of managerial and administrative workers is higher in the manufacturing sector than in other sectors. Moreover the proportion of clerical workers (group 4) in the manufacturing sector increased substantially by 7.9 percentage points while the proportion of direct production workers (groups 7, 8, and 9) fell by 21.7 points. This is consistent with the view that many local manufacturers have moved their production facilities to China and used Hong Kong mainly as a distribution and control center for their regional operation. The degree of de-industrialization in Hong Kong, then, is greater than that suggested by the decline in total manufacturing employment alone.

\section{Effect on Inter-Industry Earnings}

Observed relationship between employment and earnings depends on underlying demand and supply. If sectoral shifts are the result of the changing composition of final demand, one would expect that earnings will rise in the expanding sectors relative to the declining sectors. The magnitude of the response is a measure of the elasticity of labor supply to individual industries. On the other hand, workers' preferences might have changed. For example, some argue that as income and education improve, fewer people are interested in manufacturing work. The reduction in supply of manufacturing workers will result in reduced employment and higher wages in the manufacturing sector. To empirically

3 The numeric codes are the one-digit occupational codes according to the 1991 classification. Details of the recoding are available from me. 
distinguish these two effects requires the use of instrumental variables. However, as in most labor market studies, it is extremely difficult to find valid instruments that can safely be presumed to shift only the demand or the supply curve. In this paper I will follow most researchers (e.g., Bound and Johnson 1991; Murphy and Welch 1991; Katz and Murphy 1992) in assuming that shifts in industrial composition reflect changes in demand. A priori, this seems to be an especially reasonable assumption for the case of Hong Kong. The opening up of the Chinese economy, where average wages are about a tenth of wages in Hong Kong, is bound to have significant impact on the demand for labor in Hong Kong. The rate of economic growth in southern China has been unprecedented by historical standards, and Hong Kong's investment and trade links with it multiplied in the past decade. All these are major developments which happened in a short period of time. On the other hand, shifting preferences for employment in alternative sectors, if they happen at all, are likely to affect only the new labor market entry cohorts. The effect on the relative supply of labor to different sectors is likely to be small and gradual. These considerations partially justify the decision to treat sectoral shifts as exogenous.

Table 5 displays the regression estimates for the change in mean sectoral earnings on the change in employment shares and on other variables. The data set consists of 25 industries observed at 4 census years. Since the regressions are performed in firstdifferenced form, the effective sample size is 75. Dummy variables for the three five-year intervals are used to remove time-specific effects. The error terms are assumed to be serially correlated but independent across sectors (i.e., the covariance matrix is of the form $\left.\Sigma \otimes I_{25}\right)$. The regressions are estimated by maximum likelihood method. I concentrate on the sample of men because male workers are the more stable component of the workforce and because there were significant changes in the structure of female earnings during the period (Lui and Suen 1993). The dependent variable used in the first three regressions is the change in mean log earnings in different sectors. Column (1) indicates that changes in employment shares are only weakly correlated with changes in relative earnings: sectoral shifts account for less than .3 percent of the variation in sectoral earnings growth. Columns (2) and (3) controls for changes in demographic characteristics 
and in occupational structure in each sector. The demographic and occupational variables all come out with the expected sign. Moreover, with these control variables, the coefficient on change in employment share becomes statistically significant (at the .01 level). In the last two columns of Table 5, I controlled for demographic characteristics in a different way. For each census year, a human capital earnings regression is estimated for the sample of men. The independent variables include place of birth, marital status, activity status, education levels interacted with quartics in age, and a dummy variable for each sector. Holding all the other demographic variables at their mean value, the coefficients for the industry sector dummies will yield a predicted wage for each industry. The change in the predicted wage for each industry across census years is then be used as the dependent variable of the regression. The results are similar in pattern to those in the first three columns. ${ }^{4}$

While earnings in expanding sectors seem to rise faster than earnings in declining sectors, the magnitude of the effect is rather modest. The standard deviation of the change in employment share in the sample is about one percentage point. According to the coefficient estimates in columns (2) and (3) of Table 5, over a five year period, sectors which experience a one percentage point increase in employment share will show a 1.8 percent (1.8 log points) higher increase in earnings relative to sectors with no change in employment share. The average growth in real earnings, by contrast, is about 22.4 percent. Figure 1 gives the adjusted variable plot (see, for example, Chambers et al. 1983) of change in mean log earnings against change in employment shares after adjusting for changes in demographic and occupational structure. ${ }^{5}$ The lowess fit (Cleveland 1979) of the points near the middle is almost flat. This may be due to measurement errors in employment shares, or it may reflect genuine non-linearities in the response of earnings to sectoral shifts. The \pm 2 -standard-error bounds also show that the relationship between

4 These regressions do not hold the unobserved characteristics of workers in an industry constant since panel data are not available. The estimates would be biased if the quality of movers and stayers are systematically different.

5 The two extreme outliers are observations from the construction industry. I have removed the construction industry and re-estimated the models in Table 5. The coefficient on change in employment share falls from .018 to .014 but remains significant at the .05 level. Other coefficients are broadly similar to those shown in Table 5. 
employment growth and earnings growth is not particularly tight.

The lack of a strong relationship between employment growth and earnings growth indicates very elastic labor supply to individual sectors of the economy. Since a one percentage point increase in employment share (which corresponds to a 25 percent increase in relative employment) brings about a 1.8 percent increase in earnings, the implied elasticity of supply is $25 / 1.8=13.9$. Two factors contribute to this large measured elasticity: (1) Employment and earnings change are measured over five year intervals; and long run elasticities are typically larger than short run elasticities. (2) Classification of labor markets according to industrial sectors is an imperfect way of delineating the extent of the relevant markets (see also Stigler and Sherwin 1985). For example, an office clerk may care very little whether he works in a manufacturing firm or in a financial institution, and the amount of sector-specific human capital for such a worker is also likely to be small. These two factors suggest that concerns about a permanently depressed sector are premature. The evidence shows that Hong Kong workers are relatively mobile across industries ${ }^{6}$ so that large sectoral shifts are only associated with minor changes in relative earnings.

\section{Effect on the Disadvantaged}

The economic transformation of Hong Kong in the past decade has involved a shift towards education-intensive industries: the correlation between average years of schooling in a sector and the growth in employment share is .23 (t-statistics $=2.02)$. Other things equal, rising demand for education will increase the earnings of more educated workers relative to less educated workers. Some (e.g., Schultz 1975; Bartel and Lichtenberg 1987) have also argued that more educated workers are more flexible and adaptable to change. If this is the case, workers with relatively little education would suffer in periods of rapid economic transformation. In the United States, it is well documented that returns to education have risen sharply since the 1980s (Murphy and Welch 1989; Juhn et al. 1993). Did Hong Kong share the same experience?

6 Worker mobility across sectors need not always involve a change of jobs. It may take the form of differential entry into and differential attrition from different industries. 
To assess the changing returns to education, I have estimated a human capital earnings regression on the sample of men for each census year. The independent variables include marital status, activity status, place of birth, and six education levels interacted with quartics in age. The predicted log earning at each education level at the sample mean is then calculated. Table 6 displays the results. Panel (A) compares the predicted earnings with that of a Form 5 graduate. The returns to higher education (post-secondary and degree courses) fell sharply from 1976 to 1981 but rose from 1986 to 1991. There is little change in relative earnings for those with primary or no education. Panel (B) shows the change in log earnings at each education level. For the period 1976-81, the earnings growth of people with relatively less education was greater than those with more education. From 1981 to 1991, however, the earnings of people with less education grew slower than those with more education.

While Table 6 shows some evidence that people with little education fared less well compared to others in the 1980s, it is difficult (and too easy) to discern a trend from four data points. To investigate the changing returns to education, I have collected the unpublished tabulations from the General Household Surveys from 1976 to 1991. Figure 2 shows the real log median earnings for the sample of men with secondary, primary, and no education. The figure clearly shows that the gap between the secondary school graduates and the uneducated has widened (from about 20 percent in the late 70 s to 33 percent in the early 90s). ${ }^{7}$ The link between widening gap for the uneducated and accelerated structural change, however, remains to be established.

Another group that is commonly asserted to suffer from economic transformation is the elderly. People have argued that old people are less adaptable to change and will lose out in periods of rapid economic transformation. There is some evidence that old people are less likely to leave a declining industry and that young people are less likely to enter it. As a result the average age in a declining industry will increase. I estimate a model in which the change in average age in an industry depends on the change in

7 For people with primary education, the gap fluctuates but shows no definite increase. I have also plotted the gap between university degree holders and secondary school graduates. The earnings data for degree holders are very noisy and there does not seem to be any trend either. 
employment share. The coefficient is -.38 with an asymptotic $t$-ratio of 1.39 . However, the results in the previous section also suggest that earnings growth in declining sectors is not substantially below that in expanding sectors. If this is the case, elderly workers need not be especially hard hit by structural change.

To compare the earnings of workers of different age, I use the human capital earnings regressions estimated earlier to construct an age earnings profile for each sample year. Using the estimated profiles (which are polynomials of degree four), one can compute the growth in earnings for workers at various age. ${ }^{8}$ Figure 3 shows the earnings growth for the periods 1986-91, 1981-91 and 1986-91. Compared to younger workers, the older age groups seemed to experience slower growth during the period 1986-91, but they also experienced faster growth in the period 1981-86. Over the entire period, there is little difference in the growth of earnings by age. ${ }^{9}$ The fruits of economic growth are shared more or less equally by workers of all age.

Old age and little schooling are crude characterization of the economically disadvantaged population. A more direct classification of the disadvantaged group is based on earnings. The question about the impact of economic transformation on the disadvantaged then boils down to a question of how it affects earnings inequality. As shown in Table 7(A), the Gini coefficient for male employment earnings has risen from .386 in 1976 to .427 in 1991. Other measures of earnings inequality tell a similar story. For example, the standard deviation of log earnings has increased from .64 to .70, and the gap between the tenth percentile earning and median earning has increased by $22 \log$ points. The measures in panel (C) are based on the residuals from earnings regressions. They also indicate a trend towards greater inequality.

The trend towards greater wage inequality has been observed in a number of developed countries (e.g., Katz and Ravenga 1989; Green et al. 1992). The cause of rising

8 The computed growth rates are age-specific rather than cohort-specific.

9 The estimates are based on employed workers. If older workers who suffered large earnings loss retired early, this would induce an upward bias in the measure of the earnings of the elderly. However, while the male labor force participation rate did decline over the years, the decline was modest and steady and was probably due to the income effect. There is little evidence that early retirement accelerated as the economy was undergoing faster structural transformation. 
inequality is still a subject of active research (see, for example, Bound and Johnson 1992). In an accounting sense, sectoral shifts in Hong Kong contribute to rising wage dispersion because employment has shifted towards industries characterized by high inequality (such as the financial sector). Following Juhn et al. (1993), I decompose the variance in log earnings, $\sigma^{2}$, according to the formula:

$$
\sigma^{2}=\sum_{i} s_{i} \sigma_{i}^{2}+\sum_{i} s_{i}\left(w_{i}-\bar{w}\right)^{2}
$$

where $s_{i}$ is the employment share of sector $i, \sigma_{i}$ and $w_{i}$ are the within-sector variance and the within-sector mean of sector $i \log$ earnings, and $\bar{w}$ is the overall average log earnings. The change in variance through time can then be attributed to: (1) changes in sectoral shares; (2) changes in within-industry variance; and (3) changes in between-industry variance. Table 8 shows the result of such a decomposition. For the period 1981-91, for example, changes in industrial composition alone account for more than forty percent of the increase in variance. Changes in within-industry variance, however, remain the more important factor in the overall rise in inequality.

It is difficult to establish conclusively that structural change in Hong Kong caused rising wage inequality, although such a link remains a distinct possibility. However, in interpreting the rise in wage dispersion, two points should be borne in mind: (1) The identity of the people near the bottom of the earnings distribution in one year need to be the same as those in another year, particularly when the degree of earnings mobility is high. Longitudinal data would be needed to demonstrate conclusively that low wage workers are made relative worse off over time. (2) Unlike the experience in countries such as the United States, where real wages for low-wage jobs fell in absolute terms, real wages in Hong Kong at all levels increased sharply. For example, real earning at the tenth percentile of the distribution grew 39 percent between 1981 and 1991, even though it fell by 19 percent relative to the median. ${ }^{10}$ Changes in relative earnings must not be taken to mask the growth in real earnings.

\section{Effect on Unemployment}

\footnotetext{
10 Similarly, while workers with no education experienced a widening earnings gap relative to other workers, Figure 2 shows that their real earnings are continuously on the rise.
} 
The sectoral shifts theory of unemployment holds that periods of accelerated structural change generate labor market mismatch and increase the extent of frictional unemployment. Lilien (1982) offered some evidence for the relationship between sectoral shifts and cyclical unemployment in the United States, though this is disputed by Abraham and Katz (1986) and by Murphy and Topel (1987). For the case of Hong Kong, the relevant time series is too short to allow a detailed investigation of the relationship. I have constructed a yearly index of sectoral shifts based on 46 industries using data from the Survey of Employment, Payroll and Vacancies. Figure 4 plots the movement of this index and the movement of the unemployment rate. A quick look at the figure will dispel any concern about the effect of structural change on Hong Kong's unemployment in the recent past.

Another common concern about structural change centers around the ability of displaced workers to find new jobs. If displaced workers cannot find new jobs easily, this would show up in industry-specific unemployment rates; in particular, the industryspecific unemployment rate will rise in the declining sectors. On the other hand, if labor markets function smoothly and there is relatively little industry-specific human capital, there need not be any relationship between changes in sectoral shares and unemployment. The labor market adjustments can be achieved through wage changes and worker mobility.

I have collected quarterly employment and unemployment figures from various issues of the Quarterly Report of the General Household Survey. Industries are classified into four broad categories: manufacturing; construction; wholesale and retail trade, restaurants and hotels; and services. I constructed the industry-specific unemployment rates from the previous industry of the unemployed. The change in employment share is calculated from four-quarter difference in employment share. The resulting series extends from 1983Q1 to 1993Q2. Thus the sample contains a total of 164 observations from 4 sectors. Because of the relatively small size of the General Household Survey, some of the estimates on unemployment are infested with large standard errors. With this caveat in mind, I estimate a model in which the industry-specific unemployment rate depends on 
lag unemployment and on change in employment share. Columns (1) and (2) of Table 9 show the results. The coefficient on change in employment share is negative but is small in magnitude (a less than .1 percentage point increase in unemployment associated with every 1 percentage point fall in employment share) and statistically insignificant (at the .10 level). One problem of using ordinary least squares is that, since the unemployment rate is measured as a fraction of employment, measurement errors in industry employment will introduce a negative correlation between the disturbance term and the change in employment share. I use the lagged change in employment share as an instrumental variable and re-estimate the model. The results are displayed in the last two columns of Table 9. The magnitude and statistical significance of the coefficient on change in employment share is further reduced.

\section{Summary and Conclusions}

This paper gathers microeconomic evidence to evaluate the impact of sectoral shifts on workers in Hong Kong. Among the main findings are the following:

(1) The rate of economic transformation has accelerated since the 1980s.

(2) Earnings in expanding sectors have risen faster than earnings in declining sectors. The magnitude of the effect, however, is small and variable. A one percentage point increase (which represents a twenty five percent increase) in employment share is estimated to increase sectoral earnings by about 1.8 percent.

(3) There is some evidence that workers with no education face a widening earnings gap relative to other workers. There is no evidence that the gap between old workers and other workers has widened.

(4) The degree of wage inequality has increased. This paper, however, does not address the relation between accelerated structural change and the observed rising wage dispersion.

(5) There is no evidence that structural change increases aggregate unemployment or unemployment in declining sectors.

The findings here paint a picture of a well-functioning labor market that adapts 
smoothly to changes in labor demand. Workers in Hong Kong are relatively mobile across different economic sectors. The reallocation of labor across sectors necessitated by accelerated economic transformation has been accomplished with little effect on inter-industry wages and on unemployment. While the economically disadvantaged experienced a decline in their relative economic position, the level of their real earnings continued to rise at a rate much faster than workers in other developed countries. It is also important to point out that economic transformation in Hong Kong has mainly involved a shift towards high wage sectors. Even if real earnings in each sector had remained stagnant, the reallocation of labor from the low wage sectors to the high wage sectors would have increased average real earnings by 12.3 percent from 1976 to 1991 . During this period the actual increase in average real earnings was 78.7 percent. In other words the economic transformation of Hong Kong accounts for more than 15 percent (i.e., 12.3/78.7) of the growth in real earnings. 


\section{References}

Abraham, Katherine and Lawrence Katz. "Cyclical Unemployment: Sectoral Shifts or Aggregate Disturbances?" Journal of Political Economy 94 (June 1986): 507-522.

Bartel, Ann P. and Frank R. Lichtenberg. "The Comparative Advantage of Educated Workers in Implementing New Technology." Review of Economics and Statistics 69 (February 1987): 1:11.

Bound, John and George Johnson. "Wages in the United States During the 1980s and Beyond." In M. Kosters, ed., Workers and Their Wages. Washington: AEI Press, 1991.

—. "Changes in the Structure of Wages in the 1980's: An Evaluation of Alternative Explanations." American Economic Review 82 (June 1992): 371-392.

Census and Statistics Department. Hong Kong 1991 Population Census: Summary Report. Hong Kong: Government Printer, 1992.

Chambers, J.M., Cleveland, W.S., Keiner, B. and P.A. Tukey. Graphical Methods for Data Analysis. Belmont: Wadsworth, 1983.

Cleveland, W.S. "Robust Locally Weighted Regression and Smoothing Scatterplots." Journal of American Statistical Association 74 (December 1979): 829-836.

Green, G., Coder, J. and P. Ryscavage. "International Comparison of Earnings Inequality for Men in the 1980s." Review of Income and Wealth 38 (March 1992): $1-15$.

Greenwood, John. "The Changing Structure and Competitiveness of the Hong Kong Economy." Asian Monetary Monitor 14 (November 1990): 21-31.

Juhn, Chinhui, Murphy, Kevin M. and Brooks Pierce. "Wage Inequality and the Rise in Returns to Skill.” Journal of Political Economy 101 (June 1993): 410-442. 
Katz, Lawrence F. and Kevin M. Murphy. "Changes in Relative Wages, 1963-1987:

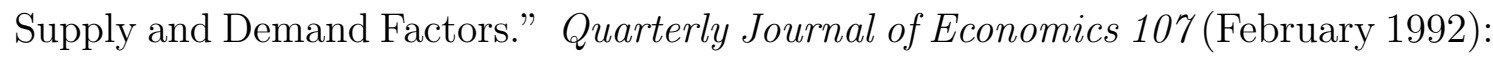
$35-78$.

Lilien, David M. "Sectoral Shifts and Cyclical Unemployment." Journal of Political Economy 90 (August 1982): 777-793.

Lui, T.L. and S. Chiu. "Industrial Restructuring and Labour-Market Adjustment under Positive Noninterventionism: The Case of Hong Kong." Environment and Planning A 25 (1993): 63-79.

Lui, Hon Kwong and Wing Suen. "The Narrowing Gender Gap in Hong Kong: 19761986." Asian Economic Journal 7 (July 1993): 167-180.

Mok, Victor. The Development and Structural Change of the Hong Kong Economy. Hong Kong: Joint Publishing, 1993.

Murphy, Kevin M. and Robert H. Topel. "The Evolution of Unemployment in the United States." NBER Macroeconomics Annual 2 (1987): 11-58.

Murphy, Kevin M. and Finis Welch. "Wage Premiums for College Graduates: Recent Growth and Possible Explanations." Educational Researcher 18 (May 1989): 17-26.

—. "The Role of International Trade in Wage Differentials." In M. Kosters, ed., Workers and Their Wages. Washington: AEI Press, 1991.

Schultz, T.W. "The Value of the Ability to Deal with Disequilibria." Journal of Economic Literature 13 (1975): 872-876.

Stigler, George J. and Robert A. Sherwin. "The Extent of the Market." Journal of Law and Economics 28 (October 1985): 555-585.

Wong, R.Y.C., Liu, P.W. and A.K.F. Siu. Inflation in Hong Kong: Patterns, Causes and Policies. Hong Kong: Business and Professional Federation of Hong Kong, 1991.

Young, Alwyn. "A Tale of Two Cities: Factor Accumulation and Technical Change in Hong Kong and Singapore." NBER Macroeconomics Annual 7 (1992): 13-54. 
Table 1

Percentage Distribution of Working Population by Industry ${ }^{a}$

\begin{tabular}{lrrrrrr}
\hline Industry & 1961 & 1971 & 1976 & 1981 & 1986 & 1991 \\
\hline Manufacturing & 43.0 & 47.0 & 44.8 & 41.3 & 35.8 & 28.2 \\
Construction & 4.9 & 5.4 & 5.6 & 7.7 & 6.2 & 6.9 \\
Electricity, gas and water & 1.1 & 0.6 & 0.5 & 0.6 & 0.7 & 0.7 \\
Transport, storage and communication & 7.3 & 7.4 & 7.4 & 7.5 & 8.0 & 9.8 \\
Wholesale and retail trade, restaurants and hotels & 14.4 & 16.2 & 19.5 & 19.2 & 22.3 & 22.5 \\
Financing, insurance, real estate and business services & 1.6 & 2.7 & 3.4 & 4.8 & 6.4 & 10.6 \\
Community, social and personal services & 18.3 & 15.0 & 15.4 & 15.6 & 18.4 & 19.9 \\
Others $^{b}$ & 9.4 & 5.7 & 3.4 & 3.3 & 2.2 & 1.4 \\
\hline
\end{tabular}

a Sources: Hong Kong 1991 Population Census: Summary Report, Hong Kong 1991 Population Census: Main Tables, Hong Kong By-Census 1976: Main Report, Vol. 1.

$b$ "Others" include agriculture, fishing, mining and quarrying, and industries not classifiable. 


\section{Table 2}

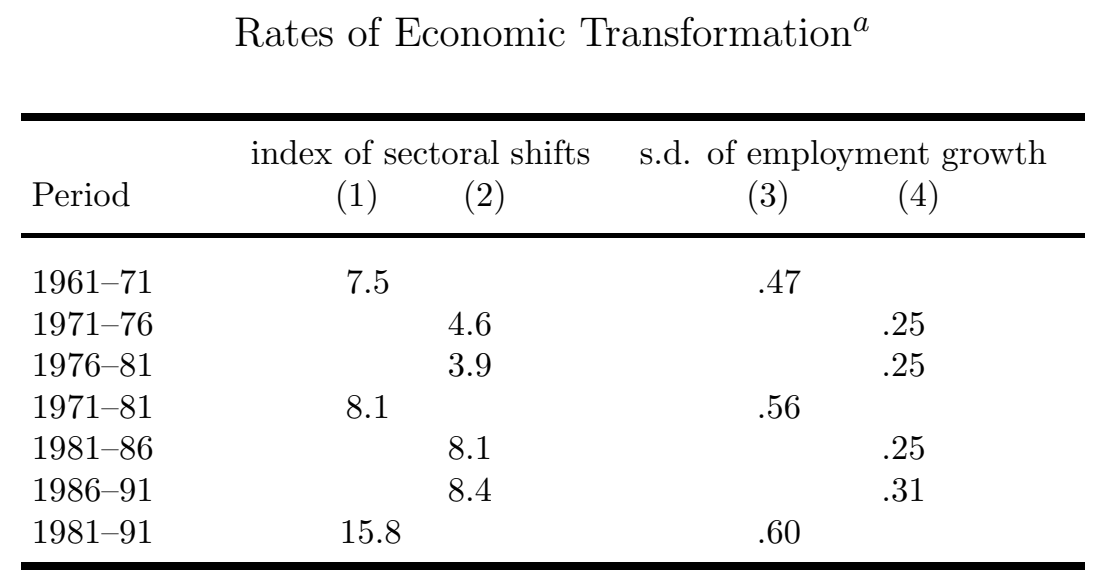

${ }^{a}$ Calculations are based on published census figures on employment in eight industries. 


\section{Table 3}

Index of Sectoral Shift: International Comparison ${ }^{a}$

\begin{tabular}{lcc}
\hline Country & $1982-86$ & $1987-92$ \\
\hline Hong Kong & 3.58 & 8.90 \\
Singapore & 5.98 & 3.27 \\
Korea & 8.48 & 6.50 \\
Japan & 2.05 & 2.22 \\
United States & 2.94 & 2.16 \\
\hline
\end{tabular}

${ }^{a}$ Calculations are based on data from the ILO Yearbook of Labor Statistics 1992. 


\section{Table 4}

Changes in Occupational Structure, 1976-91 ${ }^{a}$

\begin{tabular}{lrrrrrr}
\hline & \multicolumn{7}{c}{ Occupation Code } \\
Industry & 1 & 2,3 & 4 & 5 & 7,8 & 9 \\
\hline electricity, gas and water & 1.18 & 8.37 & -2.84 & -1.17 & 1.45 & -3.47 \\
manufacturing & 8.04 & 5.55 & 7.90 & .61 & -27.22 & 5.49 \\
construction & 4.35 & 2.72 & 1.13 & .77 & -18.48 & 10.42 \\
wholesale and retail trade, restaurants and hotels & -.11 & 2.99 & 5.35 & -.25 & .93 & -8.43 \\
transport, storage and communication & 4.06 & 4.31 & 4.81 & 2.70 & -2.75 & -12.80 \\
financing, insurance, real estate and business services & 4.12 & 13.43 & -24.38 & -4.85 & 5.91 & 5.94 \\
community, social and personal services & .07 & 2.86 & 1.25 & -13.58 & -2.33 & 13.24 \\
all industries & 4.10 & 7.70 & 6.27 & -.39 & -20.17 & 2.96 \\
\hline
\end{tabular}

${ }^{a}$ The numbers refer to the net change in the share of workers in different occupations in each industry. The unit is a percentage point. Calculations are based on unpublished census files. 


\section{Table 5}

\section{Regressions for Earnings Change ${ }^{a}$}

\begin{tabular}{|c|c|c|c|c|c|}
\hline \multirow[b]{2}{*}{ Variable } & \multicolumn{3}{|c|}{$\Delta$ Raw Earnings } & \multicolumn{2}{|c|}{$\Delta$ Adjusted Earnings } \\
\hline & (1) & $(2)$ & $(3)$ & $(4)$ & $(5)$ \\
\hline$\Delta$ employment share & $\begin{array}{c}.0041 \\
(.0107)\end{array}$ & $\begin{array}{c}.0184 \\
(.0077)\end{array}$ & $\begin{array}{c}.0182 \\
(.0069)\end{array}$ & $\begin{array}{c}.0060 \\
(.0079)\end{array}$ & $\begin{array}{c}.0114 \\
(.0070)\end{array}$ \\
\hline$\Delta$ mean age & & $\begin{array}{c}.0262 \\
(.0048)\end{array}$ & $\begin{array}{l}.0196 \\
(.0045)\end{array}$ & & \\
\hline$\Delta$ mean years of schooling & & $\begin{array}{c}.1761 \\
(.0239)\end{array}$ & $\begin{array}{c}.1457 \\
(.0232)\end{array}$ & & \\
\hline$\Delta$ fraction of managers/administrators & & & $\begin{array}{c}.7162 \\
(.1450)\end{array}$ & & $\begin{array}{c}.7528 \\
(.1442)\end{array}$ \\
\hline$\Delta$ fraction of professionals/associate professionals & & & $\begin{array}{c}.2780 \\
(.1519)\end{array}$ & & $\begin{array}{c}.1464 \\
(.1446)\end{array}$ \\
\hline dummy for $1976-81$ & $\begin{array}{c}.1448 \\
(.0194)\end{array}$ & $\begin{array}{c}.0976 \\
(.0156)\end{array}$ & $\begin{array}{c}.1017 \\
(.0159)\end{array}$ & $\begin{array}{c}.1536 \\
(.0146)\end{array}$ & $\begin{array}{c}.1520 \\
(.0136)\end{array}$ \\
\hline dummy for $1981-86$ & $\begin{array}{c}.2195 \\
(.0272)\end{array}$ & $\begin{array}{c}.1022 \\
(.0299)\end{array}$ & $\begin{array}{c}.1077 \\
(.0245)\end{array}$ & $\begin{array}{c}.2354 \\
(.0202)\end{array}$ & $\begin{array}{c}.2172 \\
(.0159)\end{array}$ \\
\hline dummy for $1986-91$ & $\begin{array}{c}.3063 \\
(.0211)\end{array}$ & $\begin{array}{c}.2135 \\
(.0192)\end{array}$ & $\begin{array}{c}.1952 \\
(.0177)\end{array}$ & $\begin{array}{c}.3067 \\
(.0156)\end{array}$ & $\begin{array}{c}.2768 \\
(.0167)\end{array}$ \\
\hline log-likelihood & 62.90 & 83.10 & 92.98 & 85.12 & 95.87 \\
\hline$R^{2}$ & .004 & .802 & .910 & .015 & .583 \\
\hline d.f. & 65 & 63 & 61 & 65 & 63 \\
\hline
\end{tabular}

${ }^{a}$ Asymtotic standard errors are in parenthesis. Sample size is 75. 
Table 6

Estimated Returns to Education

(A) LOG EARNINGS RELATIVE TO UPPER SECONDARY SCHOOL GRADUATES

\begin{tabular}{cccccccc} 
Year & No Education & Primary & Lower Secondary & Upper Secondary & Post-Secondary & & Degree \\
& & & & & & .3328 & .7642 \\
1976 & -.4038 & -.2927 & -.2111 & 0 & .2020 & .5554 \\
1981 & -.3604 & -.2312 & -.1348 & 0 & .2447 & .5447 \\
1986 & -.3973 & -.2992 & -.1876 & 0 & .3073 & .6824 \\
1991 & -.4184 & -.2941 & -.1774 & 0 & 0 \\
\hline
\end{tabular}

(B) CHANGE IN LOG EARNINGS FOR EACH EDUCATION LEVEL

Period No Education Primary Lower Secondary Upper Secondary Post-Secondary ${ }^{a}$ Degree

\begin{tabular}{ccccccc}
$1976-81$ & .1811 & .1992 & .2141 & .1377 & .0069 & -.0712 \\
$1981-86$ & .1833 & .1523 & .1675 & .2203 & .2630 & .2096 \\
$1986-91$ & .2375 & .2636 & .2688 & .2586 & .3212 & .3962 \\
$1976-91$ & .6019 & .6151 & .6503 & .6165 & .5911 & .5347 \\
\hline
\end{tabular}

${ }^{a}$ Post-secondary includes matriculation, high diploma, and non-degree courses. 
Table 7

\begin{tabular}{rlrl} 
Measures of Earnings Inequality $^{a}$ \\
\hline 1976 & 1981 & 1986 & 1991 \\
\hline
\end{tabular}

(A) Raw Earnings

Gini coefficient

$\begin{array}{llll}.386 & .382 & .410 & .427\end{array}$

(B) Log Earnings

$\begin{array}{lllll}\text { standard deviation } & .637 & .622 & .666 & .698 \\ 90-50 \text { percentile } & .811 & .752 & .833 & .916 \\ 50-10 \text { percentile } & .470 & .552 & .693 & .693 \\ 75-25 \text { percentile } & .606 & .672 & .693 & .750\end{array}$

(C) Earnings Residuals

\begin{tabular}{lllll} 
standard deviation & .492 & .499 & .515 & .532 \\
$90-50$ percentile & .526 & .535 & .545 & .581 \\
$50-10$ percentile & .545 & .574 & .620 & .615 \\
$75-25$ percentile & .519 & .523 & .545 & .571 \\
\hline
\end{tabular}

${ }^{a}$ Calculations are based on unpublished census files. 


\section{Table 8}

\begin{tabular}{lccccc}
\multicolumn{4}{c}{ Decomposition of Change in Earnings Variance ${ }^{a}$} \\
\hline & & \multicolumn{3}{c}{ Within-Industry } & \multicolumn{2}{c}{ Between-Industry } \\
Period & Total Change & variance & composition & variance composition \\
$1976-91$ & .083 & .054 & .038 & -.028 & .020 \\
$1981-91$ & .102 & .058 & .034 & .003 & .008 \\
$1986-91$ & .046 & .040 & .012 & -.008 & .001 \\
\hline
\end{tabular}

${ }^{a}$ Calculations are based on unpublished census files. 


\section{Table 9}

Regressions for Industry-Specific Unemployment Rates ${ }^{a}$

\begin{tabular}{lcccc}
\hline \multirow{2}{*}{ Variable } & \multicolumn{2}{c}{ OLS } & \multicolumn{2}{c}{ IV } \\
\hline change in employment share & $(1)$ & $(2)$ & $(3)$ & $(4)$ \\
lagged unemployment & -.0514 & -.0951 & -.0138 & -.0340 \\
& $(.0527)$ & $(.06687)$ & $(.0630)$ & $(.1006)$ \\
dummy for construction & .7798 & .6414 & .7821 & .6450 \\
& $(.0316)$ & $(.0428)$ & $(.0317)$ & $(.0431)$ \\
dummy for wholesale/retail, restaurants/hotels & & .5727 & .4805 \\
& & $(.2037)$ & & $(.2335)$ \\
dummy for services & & .2546 & .1293 \\
& & & & \\
time dummies & & $(.0313)$ & & $(.2619)$ \\
$R^{2}$ & absent & present & absent & present \\
d.f. & .795 & .872 & .794 & .871 \\
& 161 & 127 & 161 & 127 \\
\hline
\end{tabular}

${ }^{a}$ Standard errors are in parenthesis. Sample size is 164. 


\section{FIGURE 1}

Adjusted Variables Plot

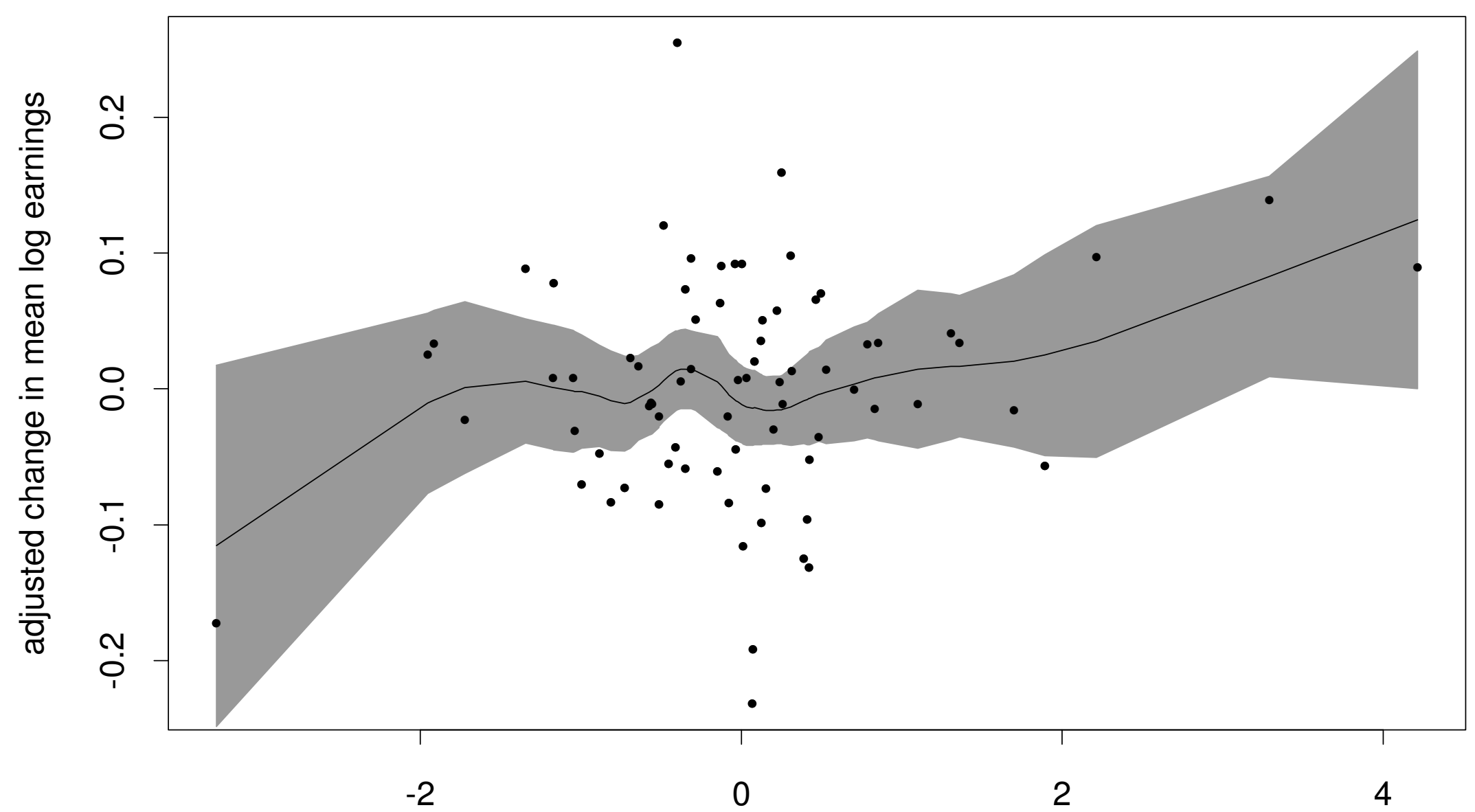

adjusted change in employment share 
FIGURE 2

Trend of Earnings by Education

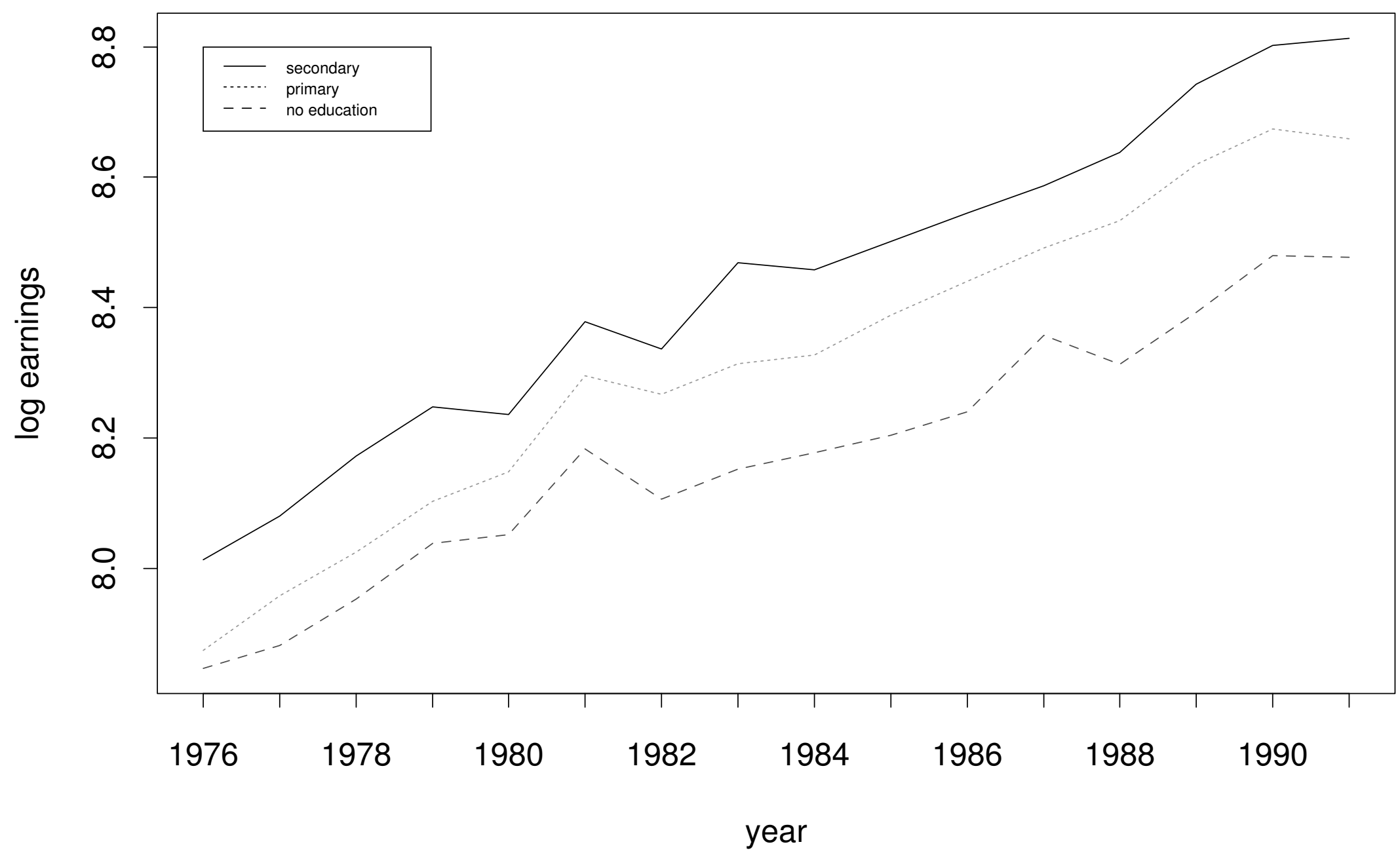


FIGURE 3

\section{Earnings Growth by Age}

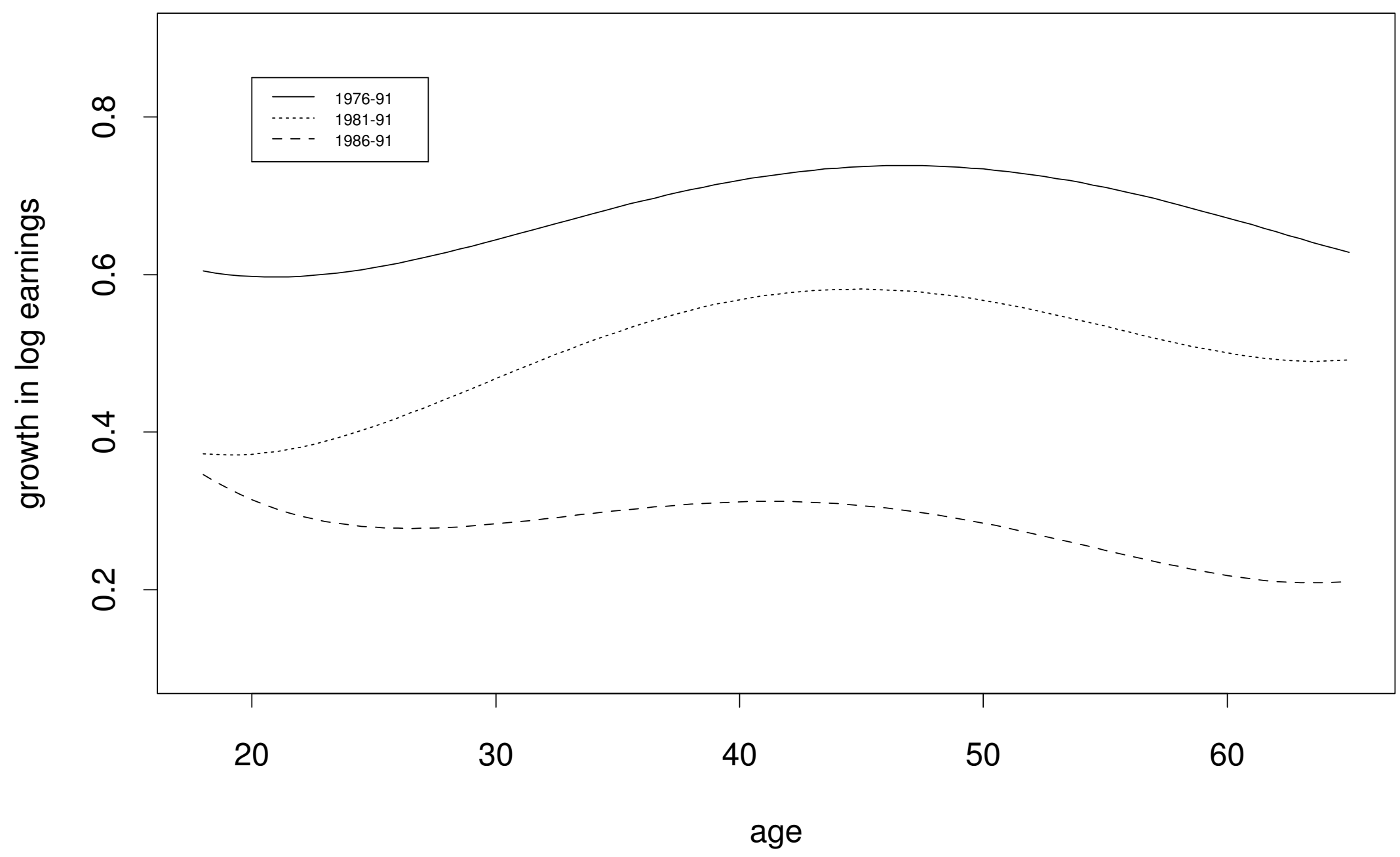


FIGURE 4

Sectoral Shift and Unemployment

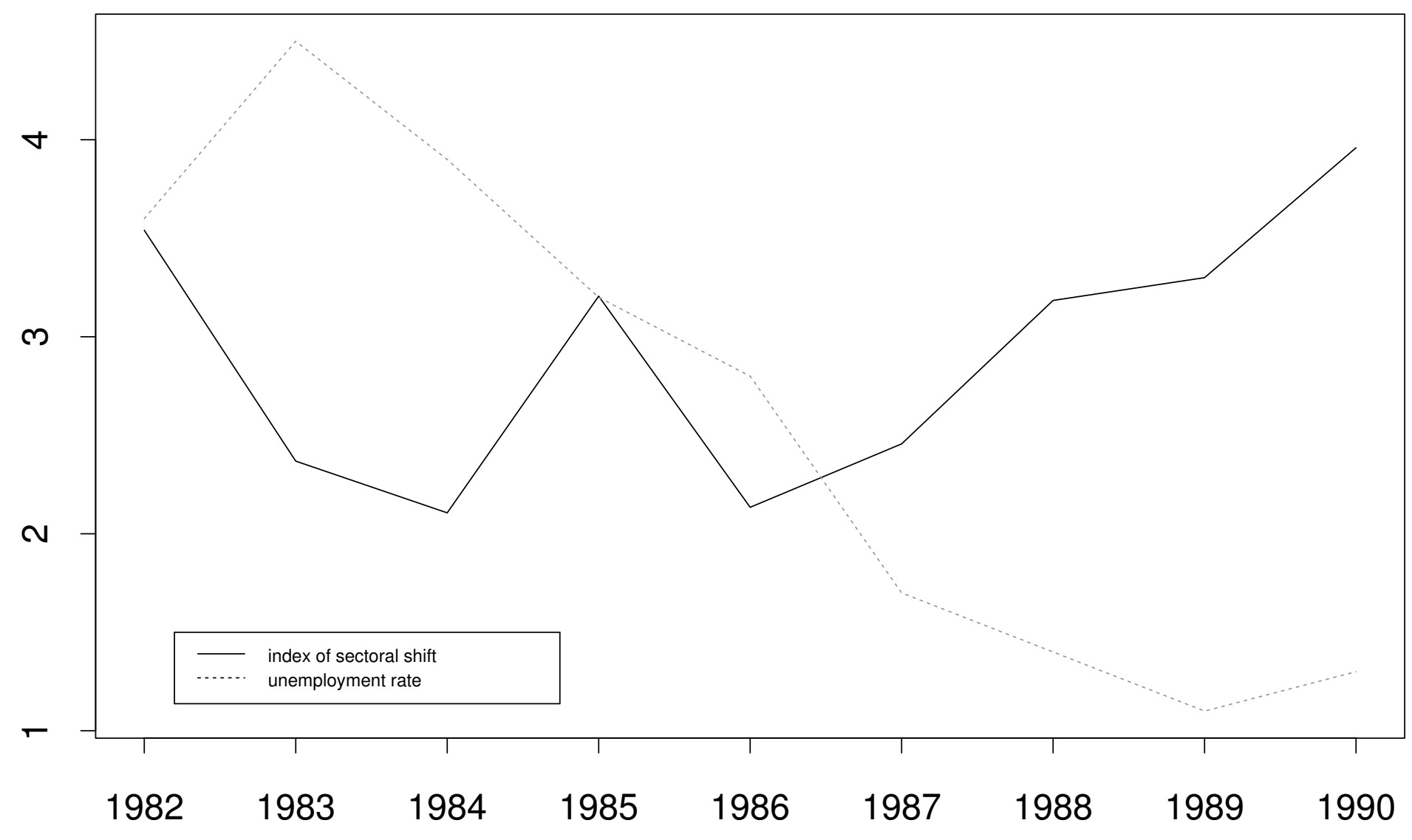

Source: Annual Digest of Statistics 1991 


\title{
SECTORAL SHIFTS: IMPACT ON HONG KONG WORKERS
}

\author{
Wing Suen* \\ University of Hong Kong
}

August 1994

* I thank Julia Cheung for able research assistance. The paper has benefited from comments by William Chan. 